\title{
Effects of addition of kaolin or cellulose to an elemental diet on intestinal cell proliferation in the mouse
}

\author{
BY R. A. GOODLAD AND N. A. WRIGHT \\ Department of Histopathology, Royal Postgraduate Medical School, \\ Hammersmith Hospital, Ducane Road, London W12 OHS
}

(Received 25 October 1982 - Accepted 17 January 1983)

1. Various methods of estimating intestinal mass and cell proliferation were used to compare the effects of a pelleted laboratory diet (diet A), an elemental diet (Flexical; diet B), Flexical plus kaolin (diet C) and Flexical plus cellulose (diet D) on the mucosa and other tissues of the mouse small intestine and colon.

2. The weight of the distal third of the small intestine was significantly decreased in mice given diets $\mathrm{B}, \mathrm{C}$ and $\mathrm{D}(P<0.001)$. The length of the colon was significantly decreased in the mice given diets $\mathrm{B}(P<0.001), \mathrm{C}$ $(P<0.01)$ and D $(P<0.05)$; however, the weight of the colon was only decreased in the mice given diet $\mathrm{B}$ or $\operatorname{diet} \mathrm{C}(P<0.001)$.

Similar changes were noted in the weights of the intestinal muscle and serosa layers; however, no such changes were noted in the weight or DNA content of the mucosa.

3. No changes were observed in the crypt cell production rate in the small intestine, apart from an increase in the mid-region $(P<0.01)$ of mice given diet $\mathrm{C}$, which was associated with a similar increase in the mucosal content of DNA.

Crypt-cell production was significantly decreased $(P<0.01,0.001)$ in the two sites of the colon studied in the mice given diets $\mathrm{B}$ or $\mathrm{C}$, but the crypt-cell production rates were not significantly different from control levels at either site in the mice given diet $D$.

4. The length of the colonic crypts was significantly decreased $(P<0.05,0.02)$ in mice given diets $\mathrm{B}$ and $\mathrm{C}$, but not in those given diet $\mathrm{D}$; total cell number showed a similar change $(P<0.01,0 \cdot 05)$.

The correlation coefficient between the length of the colonic crypts and absolute cell number was 0.513 .

5. The conclusion of the present study was that dietary fibre (cellulose), but not inert bulk (kaolin), prevents mucosal atrophy of the colon of mice given a fibre-free diet, and that many of the observed changes in intestinal weight are due to reduction in the bulk of the muscle layer.

Chemically defined or 'elemental' diets require minimal digestion and have been used to provide adequate nutrition in a variety of clinical conditions (Bury et al. 1974; Koretz \& Meyer, 1980). Several workers have observed colonic atrophy in animals given such diets (Janne et al. 1977; Storme \& Willems, 1981), and reductions in epithelial cell production and intestinal absorption have also been reported in the small intestine (Lehnert, 1979; Nelson et al. 1979). The atrophy of the distal intestine appears to be similar to that seen in animals maintained by intravenous alimentation (Morin et al. 1980). Elemental diets are, however, capable of stimulating compensatory responses in the distal intestine after intestinal resection and bypass (Fenyo \& Halberg, 1976). Colonic atrophy has been attributed to the lack of non-absorbable bulk (Ryan et al. 1979) but the same results have been quoted as proof of an effect of dietary fibre on the intestinal epithelial compartment (Sakata et al. 1980a) and growth of the colonic mucosa has been stimulated by dietary wheat-bran in rats given a fibre-free diet (Jacobs \& Schneeman, 1981).

The present paper describes the atrophic effects of an elemental diet on the mucosa and muscle of the distal small intestine and colon of the mouse and the partial reversal of these effects by the addition of fibre (cellulose), but not by inert bulk (kaolin). 


\section{METHODS}

\section{Animals}

Male Balb-c mice, 2-3 months old and weighing 20-25 g, were kept in groups of ten in wire-bottomed cages. All groups were fed ad lib and had constant access to water. Daily food intake was estimated by difference allowing for spillage.

\section{Experimental design}

The mice were divided into four groups of twenty and given the following diets for 1 week. Group A was given a pelleted diet, Labshure PRD (Labshure Ltd, Poole, Dorest). Group B was given the elemental diet Flexical (Mead Johnson Ltd, Langley, Slough). Group C was given Flexical plus $300 \mathrm{~g}$ light kaolin BP (Macarthys Ltd, Romford, Essex)/kg. Group $\mathrm{D}$ was given Flexical plus $300 \mathrm{~g}$ cellulose (Solka Floc grade BW-100, Johnsen Jorgensen $\&$ Wettre Ltd, London) $/ \mathrm{kg}$. The dietary components and proximate analyses $(\mathrm{g} / \mathrm{kg})$ of the diets were as follows.

Flexical: Sucrose, maize-syrup solids, enzymically-hydrolysed casein, tapioca starch, soya-bean oil, medium-chain triglycerides (fractionated coconut oil), citric acid, mono- and diglycerides, lecithin, amino acids (L-methionine, L-tyrosine, L-tryptophan), vitamins and minerals (protein equivalent 99, fat 150, carbohydrate 678, ash 27, moisture 15).

Labshure PRD: Barley, oats, wheat, wheatfeed, maize meal, soya-bean extracts, dried skim-milk, Torula yeast, white fish meal, minerals and vitamins (crude protein 198 , crude oil 27 , carbohydrate 538 , crude fibre 53).

The mice were killed by cervical dislocation after 1 week on these experimental diets. Ten mice were used for the cell production determinations and ten mice were used for gut weight measurements. Five of the latter group were also used for mucosal DNA estimation.

\section{Crypt-cell production rate}

Ten mice were given an intraperitoneal injection of $1 \mathrm{mg} / \mathrm{kg}$ vincristine sulphate (Oncovin, Eli Lilly \& Co. Ltd, Basingstoke)/kg at 09.00 hours and were killed at timed intervals 30-160 min later. The small intestine and colon were removed, measured and samples were taken from the following sites: site $1,10 \%$ of the length of the small intestine; site $2,25 \%$ of the length of the small intestine; site 3,50\% of the length of the small intestine; site 4 , $75 \%$ of the length of the small intestine; site $5,90 \%$ of the length of the small intestine; site $6,50 \%$ of the length of the colon; site $7,90 \%$ of the length of the colon.

Samples were opened out on to pieces of card, fixed in Carnoys fluid for $2-3 \mathrm{~h}$ and stored in ethanol $(700 \mathrm{ml} / 1)$. Small pieces of fixed tissue were later stained with the Feulgen reaction and a micro-dissection technique was used to display the intestinal crypts (Wimber \& Lamerton, 1963). The number of arrested metaphases in ten crypts was counted and the mean values were plotted $v$. time after injection. The resultant metaphase arrest line was fitted by least squares linear regression and the slope of the line gave the crypt-cell production rate (Wright \& Appleton, 1980).

\section{Measurement of colonic crypt size and cell number}

Feulgen-stained samples of colonic mucosa were placed in acetic acid $(450 \mathrm{~g} / \mathrm{l})$ and individual crypts were obtained by microdissection. The length and basal width of the crypts were measured with a microscope fitted with a calibrated eyepiece graticule. The coverslip of the microscope slide was then pressed carefully with a blunt needle to prepare a squash of single cells which were then estimated using a microscope fitted with a $10 \times 10$ eyepiece grid. 


\section{DNA estimation}

The small intestine was removed, measured and divided into three segments of equal length. Peyer's patches were carefully cut away, then the segments were rinsed with ice-cold saline ( $9 \mathrm{~g}$ sodium chloride/l) and blotted dry. The colon was also rinsed and blotted dry. The intestinal segments were then weighed and placed on a clean glass plate kept on ice and the mucosa was carefully scraped away from the serosa with a clean microscope slide. Plastic gloves were worn to prevent contamination. The serosa was weighed and the mucosa was then homogenized in ice-cold phosphate buffered saline and its DNA content assayed by the ethidium bromide fluorimetric method (Gardner \& Plumb, 1981).

\section{Statistical analysis}

Results were compared by a two-tailed Student's $t$ test for unpaired values. Crypt-cell production rates were compared by a computer-based $t$ test utilizing a pooled estimate of standard error. Crypt lengths, widths, areas and cell number were compared by the Pearson product moment correlation method.

\section{RESULTS}

Food intake and body-weights

Table 1 shows that the mean food intake was significantly increased in all groups given the experimental diets (groups B,C and D); however, although all groups given the Flexical-based diets increased in weight, this was only significant for group $\mathrm{C}(P<0 \cdot 02)$.

\section{Length and weight of intestine}

There was no difference in the length of the small intestine; however, there were significant reductions in the length of the colon in all groups given the experimental diets (see Table 2). Group B was most affected and group D was least affected.

The wet weight of the intestinal segments is also shown in Table 2 and, while no changes were seen in the proximal and mid-thirds of the small intestine, highly significant decreases were seen in the wet weight of the distal third of the small intestine in all groups given the experimental diets. The weight of the colon was also significantly $(P<0.001)$ reduced in groups $\mathbf{B}$ and $\mathrm{C}$, but not in group $\mathrm{D}$.

Table 1. The effects of dietary kaolin and cellulose on food intake and body-weights of mice given diets based on Flexical

\begin{tabular}{|c|c|c|c|c|c|c|c|c|}
\hline \multirow[t]{2}{*}{$\begin{array}{l}\text { Group... } \\
\text { Diet } \neq . . .\end{array}$} & \multicolumn{2}{|c|}{$\begin{array}{c}\text { A } \\
\text { Control }\end{array}$} & \multicolumn{2}{|c|}{$\begin{array}{l}\text { B } \\
\text { Flexical }\end{array}$} & \multicolumn{2}{|c|}{$\begin{array}{l}\text { C } \\
\text { Flexical } \\
\text { +kaolin }\end{array}$} & \multicolumn{2}{|c|}{$\begin{array}{c}\text { D } \\
\text { Flexical } \\
+ \text { cellulose }\end{array}$} \\
\hline & Mean & SEM & Mean & SEM & Mean & SEM & Mean & SEM \\
\hline Food intake $(g /$ mouse per $d)$ & $3 \cdot 3$ & $0 \cdot 1$ & $4 \cdot 2^{* * *}$ & $0 \cdot 2$ & $4 \cdot 6^{* *}$ & $0 \cdot 3$ & $4 \cdot 8^{*}$ & 0.5 \\
\hline $\begin{array}{l}\text { Body-wt (g) } \\
\text { Initial } \\
\text { Final }\end{array}$ & $\begin{array}{l}23 \cdot 3 \\
23 \cdot 2\end{array}$ & $\begin{array}{l}0.5 \\
0.6\end{array}$ & $\begin{array}{l}22 \cdot 6 \\
23 \cdot 0\end{array}$ & $\begin{array}{l}0.4 \\
0.5\end{array}$ & $\begin{array}{l}22 \cdot 7 \\
24 \cdot 7^{*}\end{array}$ & $\begin{array}{l}0.5 \\
0.4\end{array}$ & $\begin{array}{l}23 \cdot 4 \\
24 \cdot 7\end{array}$ & $\begin{array}{l}0.5 \\
0.6\end{array}$ \\
\hline Wt gain (g) & 0 & & 0.4 & & $2 \cdot 2$ & & $1 \cdot 3$ & \\
\hline
\end{tabular}

$* P<0.05, \quad * * P<0.01, \quad * * * P<0.001$.

$\dagger$ Mead Johnson Ltd, Slough, Bucks.

‡ For details, see p. 92. 
Table 2. The effects of dietary kaolin and cellulose on the length and wet weight of the intestine of mice given elemental diets based on Flexical†

\begin{tabular}{|c|c|c|c|c|c|c|c|c|}
\hline \multirow[t]{2}{*}{$\begin{array}{l}\text { Group... } \\
\text { Diet } \neq . .\end{array}$} & \multicolumn{2}{|c|}{$\begin{array}{c}\text { A } \\
\text { Control }\end{array}$} & \multicolumn{2}{|c|}{$\begin{array}{c}\text { B } \\
\text { Flexical }\end{array}$} & \multicolumn{2}{|c|}{$\stackrel{\text { C }}{\text { Flexical + kaolin }}$} & \multicolumn{2}{|c|}{$\begin{array}{c}\text { D } \\
\text { Flexical + cellulose }\end{array}$} \\
\hline & Mean & SEM & Mean & SEM & Mean & SEM & Mean & SEM \\
\hline $\begin{array}{l}\text { Length of small } \\
\text { intestine }(\mathrm{mm})\end{array}$ & 431 & 23 & 416 & 14 & 421 & 21 & 420 & 21 \\
\hline Length of colon (mm) & 107 & 8 & $90^{* * *}$ & 9 & $96^{* *}$ & 6 & $96^{*}$ & 11 \\
\hline $\begin{array}{l}\text { Wt proximal third of } \\
\text { small intestine }(\mathrm{g})\end{array}$ & 0.329 & 0.012 & 0.334 & 0.015 & $0 \cdot 325$ & 0.009 & $0 \cdot 338$ & 0.013 \\
\hline $\begin{array}{l}\text { Wt mid-third of } \\
\text { small intestine }(\mathrm{g})\end{array}$ & 0.282 & 0.013 & 0.275 & 0.014 & $0 \cdot 268$ & 0.007 & $0 \cdot 244$ & 0.011 \\
\hline $\begin{array}{l}\text { Wt distal third of } \\
\text { small intestine }(\mathrm{g})\end{array}$ & $0 \cdot 282$ & 0.013 & $0 \cdot 146^{* * *}$ & 0.007 & $0 \cdot 143^{* * *}$ & 0.005 & $0 \cdot 156^{* * *}$ & ${ }^{*} 0.012$ \\
\hline Wt of colon $(\mathrm{g})$ & 0.239 & 0.012 & $0.139^{* * *}$ & 0.008 & $0 \cdot 169^{* * *}$ & 0.009 & 0.214 & 0.021 \\
\hline
\end{tabular}

$* P<0.05, \quad * * P<0.01, \quad * * * P<0.001$.

$\dagger$ Mead Johnson Ltd, Slough, Bucks.

‡ For details, see p. 92.

Table 3. The effects of dietary kaolin and cellulose on the weight of the mucosa $(g)$ of mice given elemental diets based on Flexical ${ }^{\dagger}$

\begin{tabular}{|c|c|c|c|c|c|c|c|c|}
\hline \multirow[t]{2}{*}{$\begin{array}{l}\text { Group... } \\
\text { Diett... }\end{array}$} & \multicolumn{2}{|c|}{$\begin{array}{c}\text { A } \\
\text { Control }\end{array}$} & \multicolumn{2}{|c|}{$\begin{array}{c}\text { B } \\
\text { Flexical }\end{array}$} & \multicolumn{2}{|c|}{$\begin{array}{c}\text { C } \\
\text { Flexical } \\
+ \text { kaolin }\end{array}$} & \multicolumn{2}{|c|}{$\begin{array}{c}\text { D } \\
\text { Flexical } \\
\text { +cellulose }\end{array}$} \\
\hline & Mean & SEM & Mean & SEM & Mean & SEM & Mean & SEM \\
\hline \multicolumn{9}{|c|}{ Segments of small intestine } \\
\hline Proximal third & $0 \cdot 204$ & 0.036 & 0.232 & 0.037 & $0 \cdot 247^{*}$ & 0.018 & 0.229 & 0.026 \\
\hline Mid-third & $0 \cdot 172$ & 0.039 & $0 \cdot 200$ & 0.015 & 0.208 & 0.029 & $0 \cdot 174$ & 0.032 \\
\hline Distal third & 0.077 & 0.035 & 0.075 & 0.031 & 0.093 & 0.008 & 0.08 & 0.016 \\
\hline Colon & 0.051 & 0.017 & 0.060 & 0.018 & 0.051 & 0.016 & 0.053 & 0.007 \\
\hline
\end{tabular}

$* P<0.05$.

$\dagger$ Mead Johnson Ltd, Slough, Bucks.

$\ddagger$ For details, see p. 92.

Table 4. The effects of dietary kaolin and cellulose on the weight of the intestinal muscle and serosa $(g)$ of mice given elemental diets based on Flexical $\dagger$

\begin{tabular}{|c|c|c|c|c|c|c|c|c|}
\hline \multirow[t]{2}{*}{$\begin{array}{l}\text { Group... } \\
\text { Diet } \neq . .\end{array}$} & \multicolumn{2}{|c|}{$\begin{array}{c}\text { A } \\
\text { Control }\end{array}$} & \multicolumn{2}{|c|}{$\begin{array}{c}\text { B } \\
\text { Flexical }\end{array}$} & \multicolumn{2}{|c|}{$\begin{array}{c}\mathrm{C} \\
\text { Flexical+kaolin }\end{array}$} & \multicolumn{2}{|c|}{$\begin{array}{c}\text { D } \\
\text { Flexical }+ \text { cellulose }\end{array}$} \\
\hline & Mean & SEM & Mean & SEM & Mean & SEM & Mean & SEM \\
\hline \multicolumn{9}{|c|}{ Segment of small intestine } \\
\hline Proximal third & 0.127 & 0.008 & $0 \cdot 102$ & $0 \cdot 007$ & 0.088 & 0.005 & $0 \cdot 100$ & 0.003 \\
\hline Mid-third & $0 \cdot 119$ & 0.010 & .0 .078 & 0.010 & 0.072 & 0.006 & 0.083 & 0.009 \\
\hline Distal third & 0.088 & 0.003 & $0.061^{* * *}$ & $0 \cdot 006$ & $0.052^{* * *}$ & 0.002 & $0.051^{* * *}$ & 0.003 \\
\hline Colon & $0 \cdot 164$ & 0.007 & $0 \cdot 066^{* * *}$ & $0 \cdot 005$ & $0 \cdot 109 * *$ & $0 \cdot 008$ & $0 \cdot 123^{*}$ & 0.009 \\
\hline
\end{tabular}

${ }^{*} P<0.05, \quad{ }^{* *} P<0.01, \quad{ }^{* * *} P<0.001$.

$\uparrow$ Mead Johnson Ltd, Slough, Bucks.

$\ddagger$ For details, see p. 92. 
Table 5. The effects of dietary kaolin and cellulose on the DNA content of the intestinal mucosa ( $\mu \mathrm{g})$ of the mice given elemental diets based on Flexical $\dagger$

\begin{tabular}{|c|c|c|c|c|c|c|c|c|}
\hline \multirow[t]{2}{*}{$\begin{array}{l}\text { Group... } \\
\text { Diet }_{+} . . .\end{array}$} & \multicolumn{2}{|c|}{$\begin{array}{c}\text { A } \\
\text { Control }\end{array}$} & \multicolumn{2}{|c|}{$\begin{array}{c}\text { B } \\
\text { Flexical }\end{array}$} & \multicolumn{2}{|c|}{$\begin{array}{c}\text { C } \\
\text { Flexical } \\
+ \text { kaolin }\end{array}$} & \multicolumn{2}{|c|}{$\begin{array}{c}\text { D } \\
\text { Flexical } \\
+ \text { cellulose }\end{array}$} \\
\hline & Mean & SEM & Mean & SEM & Mean & SEM & Mean & SEM \\
\hline \multicolumn{9}{|c|}{ Segment of small intestine } \\
\hline Proximal third & $735 \cdot 5$ & $128 \cdot 4$ & $626 \cdot 6$ & $73 \cdot 3$ & 754.9 & $58 \cdot 6$ & $644 \cdot 2$ & 74.7 \\
\hline Mid-third & $385 \cdot 9$ & $57 \cdot 2$ & $552 \cdot 4$ & $55 \cdot 5$ & $702 \cdot 2^{* *}$ & $47 \cdot 4$ & $425 \cdot 0$ & $83 \cdot 2$ \\
\hline Distal third & $307 \cdot 7$ & $60 \cdot 4$ & 254.9 & $29 \cdot 1$ & 284.9 & 83.6 & $225 \cdot 3$ & $15 \cdot 2$ \\
\hline Colon & $214 \cdot 3$ & $35 \cdot 5$ & $255 \cdot 8$ & $60 \cdot 8$ & $130 \cdot 1$ & 63.5 & $123 \cdot 8$ & $32 \cdot 0$ \\
\hline
\end{tabular}

Table 6. The effects of dietary kaolin and cellulose on the crypt-cell production rate (cells/crypt per $h$ ) of mice given elemental diets based on Flexical $\dagger$

\begin{tabular}{|c|c|c|c|c|c|c|c|c|c|}
\hline \multirow{2}{*}{$\begin{array}{l}\text { Group... } \\
\text { Diet } \neq . . . \\
\\
\text { Site no. }\end{array}$} & & \multicolumn{2}{|c|}{$\begin{array}{c}\text { A } \\
\text { Control }\end{array}$} & \multicolumn{2}{|c|}{$\begin{array}{c}\text { B } \\
\text { Flexical }\end{array}$} & \multicolumn{2}{|c|}{$\begin{array}{c}\text { C } \\
\text { Flexical } \\
\text { + kaolin }\end{array}$} & \multicolumn{2}{|c|}{$\begin{array}{c}\text { D } \\
\text { Flexical } \\
\text { + cellulose }\end{array}$} \\
\hline & & Mean & SEM & Mean & SEM & Mean & SEM & Mean & SEM \\
\hline 1 & $10 \|$ & 8.43 & 1.32 & 6.82 & 2.02 & 7.96 & 1.72 & 11.45 & 1.98 \\
\hline 2 & $25 \|$ & 5.92 & 0.73 & 8.76 & 1.73 & 5.98 & 1.42 & 6.78 & $1 \cdot 16$ \\
\hline 3 & $50 \|$ & $5 \cdot 41$ & $1 \cdot 27$ & $7 \cdot 38$ & 1.40 & $9 \cdot 47^{* *}$ & 1.58 & 7.07 & 1.45 \\
\hline 4 & $75 \|$ & 6.72 & $1 \cdot 17$ & $6 \cdot 30$ & 1.24 & 8.73 & 1.90 & 6.01 & 1.41 \\
\hline 5 & $90 \|$ & $5 \cdot 53$ & 0.85 & 5.91 & 1.42 & $7 \cdot 50$ & $1 \cdot 21$ & $5 \cdot 34$ & 0.77 \\
\hline 6 & $50 \&$ & $10 \cdot 34$ & 1.20 & $5 \cdot 16^{* *}$ & 0.97 & $3 \cdot 81^{* * *}$ & 1.41 & 8.87 & 1.47 \\
\hline 7 & $90 \S$ & $11 \cdot 31$ & 1.78 & $6.99^{* *}$ & 3.26 & $4 \cdot 86^{* * *}$ & 0.97 & $10 \cdot 06$ & 1.55 \\
\hline
\end{tabular}

The weight of the mucosa and muscle and serosa are shown in Tables 3 and 4 respectively. Apart from a small increase in mucosal weight in the proximal third of the small intestine of group C $(P<0.05)$, no significant change in mucosal weight was seen; however, highly significant $(P<0.001)$ decreases in muscle and serosal weight were observed in the distal third of the small intestine of all groups given the Flexical-based diets (groups B, C and D), and in the colons of groups $\mathrm{B}(P<0.001), \mathrm{C}(P<0.01)$ and D $(P<0.05)$. The weight of the colonic muscle of group B was significantly lower than that of group $\mathrm{C}(P<0.05)$ and group $\mathrm{D}(P<0.01)$.

\section{Mucosal DNA}

There was no significant change in the mucosal DNA except for an increase $(P<0.01)$ in the mid-third of the small intestine in group C (see Table 1). 
Table 7. The effects of dietary kaolin and cellulose on morphometric estimates of the size and number of cells of the colonic crypts of mice given elemental diets based on Flexical $\$$

\begin{tabular}{|c|c|c|c|c|c|c|c|c|}
\hline \multirow{2}{*}{$\begin{array}{l}\text { Group... } \\
\text { Diet\|... } \\
\text { Crypt-cell }\end{array}$} & \multicolumn{2}{|c|}{$\begin{array}{c}\text { A } \\
\text { Control }\end{array}$} & \multicolumn{2}{|c|}{$\begin{array}{c}\text { B } \\
\text { Flexical }\end{array}$} & \multicolumn{2}{|c|}{$\begin{array}{c}\text { C } \\
\text { Flexical } \\
\text { + kaolin }\end{array}$} & \multicolumn{2}{|c|}{$\begin{array}{c}\text { D } \\
\text { Flexical } \\
+ \text { cellulose }\end{array}$} \\
\hline & Mean & SEM & Mean & SEM & Mean & SEM & Mean & SEM \\
\hline $\begin{array}{l}\text { Length }(\mu \mathrm{m}) \\
\text { Number }\end{array}$ & $\begin{array}{l}282 \cdot 9 \\
387 \cdot 1\end{array}$ & $\begin{array}{l}14 \cdot 3 \\
29 \cdot 4\end{array}$ & $\begin{array}{l}240 \cdot 4^{*} \\
257 \cdot 6^{* *}\end{array}$ & $\begin{array}{r}11.8 \\
9.0\end{array}$ & $\begin{array}{l}228 \cdot 4 \dagger \\
301.9^{*}\end{array}$ & $\begin{array}{l}13 \cdot 2 \\
17 \cdot 3\end{array}$ & $\begin{array}{l}291.5 \\
393.7\end{array}$ & $\begin{array}{l}17 \cdot 4 \\
33 \cdot 8\end{array}$ \\
\hline
\end{tabular}

\footnotetext{
$* P<0.05, \quad{ }^{* *} P<0.01$.

$\dagger P<0.02$.

† Mead Johnson Ltd, Slough, Bucks.

|| For details, see p, 92.
}

\section{Crypt-cell production rate}

The rate of entry of cells into mitosis per crypt, or crypt-cell production rate, is shown in Table 6. No significant changes in crypt-cell production rate were seen in the small intestine, apart for an increase in site 3 of group $C(P<0.01)$. Crypt-cell production was significantly reduced in both the colonic sites (sites 6 and 7) of groups $\mathrm{B}$ and $\mathrm{C}$; however, the crypt-cell production rate in the colonic sites of group D was not significantly smaller than that of the control group.

\section{Morphometric estimates of the size of the colonic crypts}

The correlation coefficient between measured crypt length and cell number (as determined by direct counting) was $0.513(n=45)$. The correlation between basal crypt width and cell number was $0 \cdot 114$. The correlation between crypt area and cell number was 0.424 . Crypt area was calculated using the equation, area $=\pi W+L+\pi(1 / 2 W) 2$, where $W$ is the basal crypt width and $L$ is the crypt length.

Both colonic crypt length and cell number were significantly decreased in groups B and C, but not in group D (see Table 7).

\section{DISCUSSION}

There was an increase in food intake of all groups given the experimental diets (groups B, $\mathrm{C}$ and $\mathrm{D}$ ), with the greatest increase occurring in groups $\mathrm{C}$ and $\mathrm{D}$. Increased food intake with increased bulk has been reported by Dowling et al. (1967). Diet C contained $300 \mathrm{~g}$ inert bulk $/ \mathrm{kg}$ and diet $\mathrm{D}$ contained $300 \mathrm{~g}$ cellulose of limited digestibility $/ \mathrm{kg}$, thus the metabolizable energy intake of groups $C$ and $D$ would only have been marginally increased when compared with the control group (group A; gross energy of Flexical $18.5 \mathrm{~kJ} / \mathrm{g}$ ).

The body-weight of all groups given the Flexical-based diets also increased, but the weight increase of group B (Flexical alone) was less than that of groups $C$ and $D$ despite the greater metabolizable energy intake of group B.

The weight increase of group C (Flexical plus kaolin) was the greatest of all the groups despite this group having the lowest energy intake. Group $\mathrm{C}$ was also the only group to show a change in the proximal small intestine, as mucosal weight, crypt-cell production rate and mucosal DNA content were all increased in some segments. Dowling et al. (1967) also found an increase in jejunal absorptive capacity after feeding kaolin to rats. This could have been due to improved luminal mixing, increased intestinal transit time, slowed gastric emptying or to a reduction in or absorption of pancreatic-biliary secretions (Weser et al. 
1982). Nelson et al. (1981) have reported decreased jejunal and ileal water absorption in rats given Flexical, but this was associated with increased villus height and decreased crypt depth, which suggests a decrease in epithelial cell proliferation with aged villus cells. Crypt or villus height is not necessarily a very good method of estimating cell number (Wright, 1982) and the present study shows that even in a structure as simple as the colonic crypts the correlation between length and cell number is not very good. A small increase in jejunal cell renewal (but not to control values) after the addition of cellulose and vaseline to an elemental diet has been reported by Echnauer et al. (1981).

The weight of the distal third of the small intestine decreased in all groups given Flexical-based diets, but this was due to muscular atrophy. Weight loss was also observed in the colons of groups B, C and D, and this was the result of loss of muscle weight. Group B lost most muscle weight and group D lost least. Although no significant changes in mucosal weight were observed in the colon, significant reductions in crypt-cell production, crypt length and crypt-cell number were observed in groups B and C, but not in group D. The mucosal weight was relatively low and the errors of measurement of weight and DNA were quite large; thus their failure to detect the previously-described changes is not very surprising. The decrease in cell production, crypt length and cell number in the colons of groups $B$ and $C$ suggests that while inert bulk may reduce the atrophy of colonic muscle induced by the elemental diet, it cannot prevent the reduction in epithelial proliferation and crypt size. The cellulose in diet $\mathrm{D}$, however, was more effective in reducing the atrophy of the muscle layer and prevented the decrease in colonic epithelial proliferation and crypt size. Decreases in colonic muscle mass in rats given low residue diets have been associated with diverticular disease in rats (Carlson \& Hoelzel 1949; Havia \& Klossner, 1971).

The results of the present study suggest that the epithelial and muscle layers of the colon can change independently, and that the colon is similar to the rumen in that, while inert bulk can stimulate the muscle, the presence of digestible or fermentable food is necessary for the development or maintenance of the mucosa (Flatt et al. 1958; Sakata et al. 1980 b).

Cellulose can be digested in the rodent colon (Nyman \& Asp, 1982) and this occurs via the action of micro-organisms (Eggum et al. 1982). Microbial fermentation in the colon produces volatile fatty acids (Cummings, 1981) and isolated rodent colonocytes metabolize butyrate in preference to other substrates (Roediger, 1982). It is very tempting to speculate that, as in the rumen (Sakata et al. 1980 b), cell proliferation in the colon is directly or indirectly stimulated by the release of volatile fatty acids, especially as the morphology of the rodent colon and small intestine is profoundly altered by its microbial status (Clarke, 1973; Komai \& Kumura, 1980). Several other mechanisms could, however, explain the present results, and it is still not known whether any of the Western diseases associated with a low-fibre intake (Trowell, 1978) are the result of altered intestinal epithelial proliferation or muscle mass, or if they are the result of the many other factors involved, such as the time the digesta stays in the colon, water-holding and binding of bile acids and carcinogens.

The authors wish to thank Dr Jane A. Plumb for her help with the DNA assay, and the Cancer Research Campaign for their financial assistance. They also wish to thank Mead Johnson Ltd for the Flexical and Johnsen Jorgensen \& Wettre Ltd for the Solka Floc.

REFERENCES

Bury, K. D., Stephens, R. V., Cha, C. J. \& Randall, H. T. (1974). Canadian Journal of Surgery 17, 124-134.

Carlson, A. J. \& Hoelzel, F. (1949). Gastroenterology 12, 108-115.

Clarke, R. M. (1973). Laboratory Animals 9, 201-209.

Cummings, J. H. (1981). Gut 22, 763-779.

Dowling, R. H., Reicken, E. O., Laws, J. W. \& Booth, C. C. (1967). Clinical Science 32, 1-9. 
Ecknauer, R., Sircar, B. \& Johnson, L. R. (1981). Gastroenterology 81, 781-786.

Eggum, B. O., Thorbek, G., Beames, R. M., Chwalibog, A. \& Henckel, S. (1982). British Journal of Nutrition 48 , 161-175.

Fenyo, G. \& Hallberg, D. (1976). Acta Chirurgica Scandinavica 142, 270-274.

Flatt, W. P., Warner, R. G. \& Loosli, J. K. (1955). Journal of Dairy Science 41, 1593-1600.

Gardner, M. L. G. \& Plumb, J. A. (1981). Biochemical Pharmacology 30, 201-207.

Havia, T. \& Klossner, J. (1971). Annales Chirurgiae et Gynaecologiae 60, 132-134.

Jacobs, L. R. \& Schneeman, B. O. (1981). Journal of Nutrition 115, 798-803.

Janne, P., Carpentier, Y. \& Willems, G. (1977). American Journal of Digestive Diseases 22, 808-812.

Komai, M. \& Kumura, S. (1980). Journal of Nutrition Science and Vitaminology 26, 389-399.

Koretz, R. L. \& Meyer, J. H. (1980). Gastroenterology 78, 393-410.

Lehnert, S. (1979). Cell \& Tissue Kinetics 12, 239-248.

LePecq, J. B. \& Paoletti, C. (1966). Analytical Biochemistry 17, 100-107.

Morin, C. L., Ling, V. \& Bourassa, D. (1980). Digestive Diseases and Sciences 25, 123-128.

Nelson, L. M., Carmichael, H. A., Russel, R. I. \& Lee, F. D. (1979). Clinical Science and Molecular Medicine 55, 509-511.

Nelson, L. M., Russel, R. I. \& Lee, F. D. (1981). Journal of Parenteral and Enteral Nutrition 5, $204-206$.

Nyman, M. \& Asp, N. G. (1982). British Journal of Nutrition 47, 357-366.

Roediger, W. E. W. (1982). Gastroenterology 83, 424-429.

Ryan, G. P., Dudrick, S. J., Copeland, E. M. \& Johnson, L. R. (1979). Gastroenterology 77, $658-663$.

Sakata, T., Hikosaka, K., Shiomura, Y. \& Tamate, H. (1980a). British Journal of Nutrition 44, $325-331$.

Sakata, T., Hikosaka, K., Shiomura, Y. \& Tamate, H. (1980 b). In Cell Proliferation in the Gastrointestinal Tract, pp. 123-137 [D. R. Appleton, J. P. Sunter and A. C, Watson, editors] Bath: Pitman Press.

Storme, G. \& Willems, G. (1981). Cell and Tissue Research 216, 221-225.

Trowell, H. C. (1978). In Dietary Fibre: Current Developments of Importance to Health, pp. 1-8 [K. W. Heaton, editor] London: John Libbey.

Weser, E., Drummond, A. \& Tawil, T. (1982). Journal of Parenteral and Enteral Nutrition 6, $39-43$.

Wimber, D. E. \& Lamerton, L. F. (1963). Radiation Research 18, 137-146.

Wright, N. A. (1982). Scandinavian Journal of Gastroenterology 17 (Suppl. 74), 3-11.

Wright, N. A. \& Appleton, D. R. (1980). Cell and Tissue Kinetics 13, 643-663. 